Tersedia online di: http://ejournal-balitbang.kkp.go.id/index.php/bawal
e-mail:bawal.puslitbangkan@ gmail.com
BAWAL wIDYA RISET PERIKANAN TANGKAP
Volume 9 Nomor 2 Agustus 2017
p-ISSN: 1907-8226
e-ISSN: 2502-6410
BAWAL
Nomor Akreditasi: 620/AU2/P2MI-LIPI/03/2015

\title{
BIOLOGI REPRODUKSI IKAN LIDAH, (Cynoglossus cynoglossus, Hamilton 1822) PISCES: CYNOGLOSSIDAE DI TELUK PABEAN, JAWA BARAT
}

\section{REPRODUCTIVE BIOLOGY OF TONGUE SOLE, (Cynoglossus cynoglossus, Hamilton 1822) PISCES: CYNOGLOSSIDAE IN PABEAN BAY, WEST JAVA}

\author{
Arinie Gustiarisanie ${ }^{* 1}$, M. F. Rahardjo ${ }^{23}$ dan Yunizar Ernawati ${ }^{2}$ \\ ${ }^{1}$ Program Studi Pengelolaan Sumber Daya Perairan SPs, Jalan Agatis Kampus IPB Dramaga, Bogor 11680 \\ ${ }^{2}$ Departemen Manajemen Sumber Daya Perairan FPIK, Jalan Agatis Kampus IPB Dramaga, Bogor 11680 \\ ${ }^{3}$ Masyarakat Iktiologi Indonesia, Puslit Biologi-LIPI Gd. Widyasatwaloka. Jl. Raya Cibinong Km 46, Cibinong 16911 \\ Teregistrasi I tanggal: 23 Januari 2017; Diterima setelah perbaikan tanggal: 11 Agustus 2017; \\ Disetujui terbit tanggal: 06 Nopember 2017
}

\begin{abstract}
ABSTRAK
Ikan Cynoglossus cynoglossus termasuk dalam famili Cynoglossidae yang hidupnya menetap di dasar perairan. Di Teluk Pabean, ikan ini dimanfaatkan oleh masyarakat untuk dikonsumsi sendiri dan untuk dijual. Tujuan penelitian ini adalah untuk mengetahui aspek biologi reproduksi ikan C. cynoglossus yang mencakup ukuran ikan pertama kali matang gonad, musim dan tipe pemijahan. Penelitian dilakukan pada Januari-Desember 2015 di perairan Teluk Pabean, Kabupaten Indramayu. Pengambilan contoh dilakukan setiap bulan sekali dengan menggunakan alat tangkap sero. Diperoleh jenis ikan 613 ekor terdiri dari 290 ekor ikan jantan dan 323 ekor betina. Distribusi ukuran panjang total berkisar Antara 46-117 mm (jantan), 61-126 mm (betina) dengan bobot tubuh berkisar antara 0,57-8,75 g (jantan), dan 2,81-16,72 g (betina). Ukuran ikan betina pertama kali matang gonad pada panjang total $105,5 \mathrm{~mm}$. Ikan ini termasuk pemijah bertahap dengan jumlah telur berkisar antara 2.657-39.647 butir.
\end{abstract}

Kata Kunci: Cynoglossus cynoglossus; Teluk Pabean; pemijahan; fekunditas

\section{ABSTRACT}

In the Pabean Bay, Tonguesole (Cynoglossidae) has important value to the community. This research aims to investigate some reproductive biology aspects of tongue sole, namely length at first maturity, spawning season and type of spawn. The research conducted in January to December 2015 in the Pabean Bay, Indramayu. Monthly enumeration conducted from sample that collected through trap net by 613 fishes (290 males and 323 females). The total length of fish ranged from 46 to $117 \mathrm{~mm}$ (males), 61 to $126 \mathrm{~mm}$ (females). While, the body weight of the fish ranged from 0.57 to 8.75 gram (males), 2.81 to 16.72 gram (females). The results showed that the first maturity of the female is about $105.5 \mathrm{~mm}$ total length. This species is probably a batch spawner with the number of eggs ranges from 2657 to 39647 grains.

Keywords: Cynoglossus cynoglossus; Pabean Bay; spawning; fecundity

\section{PENDAHULUAN}

Teluk Pabean merupakan perairan estuaria tempat bermuaranya Sungai Cimanuk lama, Cimanuk baru dan juga anak Sungai Cimanuk yang selalu mengalami kondisi air yang berfluktuasi, terutama salinitasnya. Kondisi perairan Korespondensi penulis:

e-mail:ariengustia@yahoo.com

Telp. 085274868898 yang berfluktuasi ini akan mempengaruhi berbagai aspek biologi ikan antara lain reproduksi. Setiap ikan akan melakukan adaptasi terhadap lingkungannnya baik itu secara fisik, kimiawi, maupun hayati agar proses reproduksi dapat terus berlangsung. 
Salah satu jenis ikan dasar yang terdapat di perairan Teluk Pabean adalah ikan lidah (Cynoglossus cynoglossus) (Lampiran 1). Ikan lidah termasuk famili Cynoglossidae yang hidup di dasar perairan. Ikan ini banyak ditemukan di perairan laut dan daerah estuaria dengan substrat berlumpur dan berpasir. Ikan ini pasif bergerak sehingga penyebarannya tidak terlalu jauh serta memiliki keunikan metamorfosis dari bentuk simetri bilateral pada fase larva menjadi non-simetri bilateral pada fase juvenil (Bal \& Rao, 1984; Kramer, 1991; Zahid \& Simanjuntak, 2009).

Ciri morfologi ikan lidah adalah memiliki tubuh memanjang, mata tidak berdekatan, moncong bulat, pengait di bawah mulut (rostral hook) pendek, jumlah jari-jari sirip punggung berkisar Antara 93-102, jari-jari sirip perut berkisar 70-78 dan jari-jari sirip ekor berjumlah 10-12. Ikan ini mempunyai dua linea lateralis dimulai dari ujung mulut hingga perlipatan sirip ekor dan warna ikan ini coklat keabuan (Carpenter \& Niem, 2001; Nelson, 2006). Secara geografis, ikan lidah tersebar hampir di sepanjang wilayah Indo-Pasifik barat, Taiwan, Tiongkok selatan, Jepang, kearah timur Filipina sampai kearah selatan Papua Nugini, dan Australia (Carpenter \& Niem, 2001; Munroe, 2005). Secara ekologi banyak ditemukan di perairan laut, pantai, dan daerah estuaria dengan substrat pasir dan berlumpur (Damalas et al., 2009).

Di Teluk Pabean, ikan lidah dikenal dengan nama lokal ikan ilat-ilat. Ikan ini dimanfaatkan oleh masyarakat untuk dikonsumsi sendiri dan dijual lokal. Alat tangkap yang sering digunakan untuk menangkap adalah sero. Sero merupakan alat tangkap pasif dengan ukuran mata jaring 2 mm sehingga semua jenis ukuran ikan akan tertangkap. Aktifitas nelayan seperti penangkapan dapat memengaruhi dinamika populasi, pertumbuhan, reproduksi, habitat ikan serta memberikan dampak luas baik secara langsung maupun tidak langsung yang menyebabkan ketidakseimbangan fungsi ekosistem dan populasi ikan (Jennings \& Lock, 1996; Jennings \& Kaiser, 1998; Pauly et al., 2002). Pencegahan ini dapat dilakukan dengan cara mengelola sumber daya secara berkelanjutan dengan mempertimbangkan aspek ekobiologi ikan, yang salah satunya yaitu aspek biologi reproduksi.

Penelitian mengenai biologi reproduksi dan faktor kondisi ikan lidah $C$. bilineatus telah dilakukan di Pantai Mayangan (Zahid \& Simanjuntak, 2009), serta di Ujung Pangkah oleh Sulistiono et al. (2009). Diduga ada perbedaan tipologi perairan terhadap kondisi ikan termasuk pada aspek reproduksi. Jika sebelumnya penelitian berlangsung pada tipe perairan pantai yang berhubungan langsung dengan laut, maka penelitian ini berlangsung di perairan bertipe teluk. Informasi ini sangat menarik dan perlu diteliti karena reproduksi merupakan kunci keberlanjutan suatu populasi ikan untuk tetap ada sehingga tidak terjadi kepunahan. Dengan mengetahui aspek biologi reproduksi tersebut maka penangkapan dapat dilakukan secara optimal dengan mempertimbangkan hal-hal yang dapat menurunkan populasi ikan lidah agar kelestariannya tetap terjaga.

Tujuan penelitian ini adalah untuk mengetahui aspek biologi reproduksi ikan $C$. cynoglossus yang mencakup ukuran ikan pertama kali matang gonad, musim pemijahan, dan tipe pemijahan.

\section{BAHANDANMETODE}

Penelitian ini dilakukan selama satu tahun dari JanuariDesember 2015 dengan pengamatan satu kali dalam sebulan di perairan Teluk Pabean, Kabupaten Indramayu (Gambar 1).

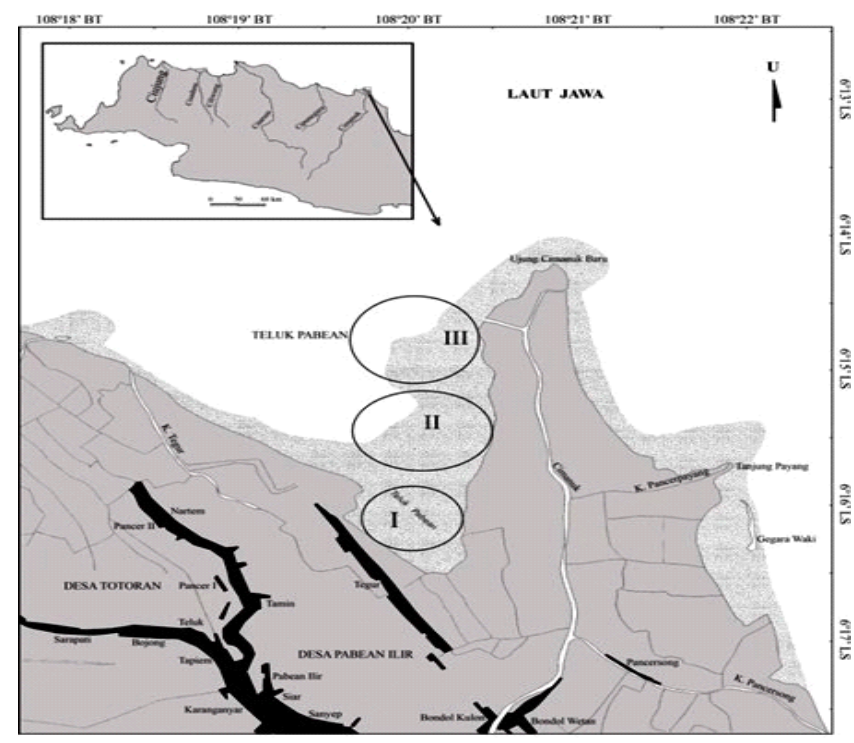

Gambar 1. Peta lokasi penelitian di Teluk Pabean (Sumber: Modifikasi Bakosurtanal).

Figure 1. Map of research sites in Pabean Bay (Source: Bakosurtanal Modification). 
Untuk mendapatkan data yang representatif, pengambilan ikan contoh dilakukan pada tiga zona sampling berdasarkan karakteristik area, yakni Zona I merupakan area mangrove, Zona II merupakan area yang berdekatan dengan aktivitas tambak ikan bandeng, dan Zona III merupakan area yang paling banyak pemasangan alat tangkap sero.

Alat tangkap yang digunakan adalah sero berukuran mata jaring $2 \mathrm{~mm}$ dengan ketinggian $1 \mathrm{~m}$. Pada prinsipnya alat tangkap ini terdiri atas 4 bagian penting masing-masing disebut: penajo (main fence), sayap (wing), badan (body), dan bunuhan (crib). Panjang penajo bervariasi, tergantung besar kecilnya sero. Sero berukuran besar panjang penajo dapat mencapai antara 300-500 meter dan sero berukuran kecil mencapai 100-300 meter. Panjang sayap \pm 60 meter dan tinggi sayap $\pm 1,2$ meter. Badan terdiri atas kamarkamar (chamber), banyaknya kamar-kamar bervariasi bergantung kepada ukuran sero. Sero kecil umumnya terdiri atas 1-2 kamar dan untuk sero besar 4 kamar. Bunuhan atau juga disebut kantong sero berguna untuk menampung ikan-ikan yang sudah terperangkap. Panjang kantong sero 3 meter, lebar 2 meter, dan tinggi 2,5 meter. Sero merupakan alat tangkap permanen nelayan di daerah tersebut. Sero biasanya dioperasikan nelayan pada sore hari dan diangkat pada pagi hari.

Contoh ikan yang tertangkap diawetkan dengan formalin 10\% dan kemudian dianalisis di laboratorium. Biologi Makro I, Departemen Manajemen Sumber Daya Perairan Fakultas Perikanan dan Ilmu Kelautan Institut Pertanian Bogor. Setiap contoh diukur panjang totalnya dengan menggunakan kaliper digital berketelitian $1 \mathrm{~mm}$. Bobot tubuh ikan ditimbang menggunakan timbangan digital berketelitian $0,01 \mathrm{~g}$.

Contoh ikan dibedah tanpa merusak organ pada ikan untuk mengeluarkan gonadnya. Tingkat kematangan gonad ditentukan secara makroskopis (Tabel 1). Gonad ditimbang dengan menggunakan timbangan digital berketelitian 0,0001 g. Bobot gonad dengan bobot tubuh ikan akan dibandingkan untuk menghitung indeks kematangan gonad dengan menggunakan rumus sebagai berikut (Effendie, 1979):

$$
I K G=\frac{W g}{W t}
$$

Keterangan:

Wg : Bobot gonad ikan (gram)

Wt : Bobot tubuh ikan (gram)

Untuk mendapatkan ukuran pertama kali matang gonad dianalisis berdasarkan panjang total yang ditentukan dengan metode pendekatan berdasarkan ukuran morfometrik (Shabana et al., 2012).

Fekunditas total dihitung dengan menggunakan metode gravimetrik pada ikan betina yang matang gonad (TKG IV) dengan rumus sebagai berikut (Effendie, 1979):

$$
F=\frac{G}{g} X N
$$

Keterangan:

F : Fekunditas total (butir)

$\mathrm{G}$ : Bobot gonad total (gram)

g : Bobot gonad contoh (gram)

$\mathrm{N}$ : Jumlah telur tercacah (butir)

Pada pengukuran diameter telur, diambil sebanyak 50 butir telur ikan betina yang matang gonad (TKG IV) dari ovarium bagian anterior, tengah dan posterior. Telur yang diambil disusun pada gelas obyek dan diamati dengan menggunakan mikroskop pada perbesaran 4 x 10 yang telah dilengkapi dengan mikrometer okuler yang sebelumnya sudah ditera dengan mikrometer objektif. Hasil pengukuran dibuat histogram distribusi diameter telur. Data ini digunakan sebagai dasar penentuan tipe pemijahan ikan.

Musim pemijahan diduga dari nilai persentase ikan betina yang matang gonad (TKG IV) yang tertangkap selama penelitian. Waktu puncak pemijahan adalah bulan ketika paling banyak ditemukan ikan betina yang matang gonad (TKG IV). 
Tabel 1. Ciri morfologi gonad ikan (Rahardjo, 1987)

Table1. Characteristic of gonadal morphology of fish (Rahardjo, 1987)

\begin{tabular}{|c|c|c|}
\hline $\begin{array}{l}\text { TKG/Gonad Maturity } \\
\text { Stage }\end{array}$ & Betina/Female & Jantan/Male \\
\hline $\begin{array}{c}\mathrm{I} \\
(\text { Immature })\end{array}$ & $\begin{array}{l}\text { Gonad seperti sepasang benang yang } \\
\text { memanjang pada sisi lateral dalam } \\
\text { rongga perut, transparan dengan } \\
\text { permukaan licin }\end{array}$ & $\begin{array}{l}\text { Gonad seperti sepasang benang, tap } \\
\text { lebih pendek daripada gonad ikan } \\
\text { betina pada tingkat dan ukuran yang } \\
\text { relatif sama. warna kemerahan }\end{array}$ \\
\hline $\begin{array}{c}\mathrm{II} \\
\text { (Developing) }\end{array}$ & $\begin{array}{l}\text { Gonad berukuran lebih besar dan } \\
\text { bewarna kekuningan, butiran telur } \\
\text { belum dapat dilihat dengan mata } \\
\text { telanjang }\end{array}$ & $\begin{array}{l}\text { Gonad berukuran lebih besar dan } \\
\text { bewarna putih santan }\end{array}$ \\
\hline $\begin{array}{c}\text { III } \\
\text { (Mature) }\end{array}$ & $\begin{array}{l}\text { Gonad mengisi hampir separuh } \\
\text { rongga perut, butiran telur sudah } \\
\text { mulai dapat dilihat namun masih } \\
\text { terlalu kecil. Warna kuning }\end{array}$ & $\begin{array}{l}\text { Ukuran gonad relatif lebih besar } \\
\text { sehingga dapat mengisi hampir } \\
\text { separuh rongga perut. Warna putih }\end{array}$ \\
\hline $\begin{array}{l}\text { IV } \\
\text { (Ripe) }\end{array}$ & $\begin{array}{l}\text { Gonad mengisi sebagian besar rongga } \\
\text { perut, bewarna kuning. Butiran telur } \\
\text { dapat dilihat secara jelas dengan kasat } \\
\text { mata }\end{array}$ & $\begin{array}{l}\text { Gonad semakin besar ukurannya, } \\
\text { semakin pejal, dan mengisi sebagian } \\
\text { besar rongga perut. Bewarna putih }\end{array}$ \\
\hline $\begin{array}{c}\mathrm{V} \\
(\text { Spent })\end{array}$ & $\begin{array}{l}\text { Warna gonad serupa dengan TKG IV, } \\
\text { gonad lebih pendek dan kecil daripada } \\
\text { TKG sebelumnya }\end{array}$ & $\begin{array}{l}\text { Gonad sudah terlihat lebih kecil dan } \\
\text { lembek, warna serupa dengan TKG IV }\end{array}$ \\
\hline
\end{tabular}

\section{HASIL DAN BAHASAN}

Hasil

Jumlah ikan C. cynoglossus yang tertangkap selama penelitian sebanyak 613 ekor terdiri atas 290 ekor ikan jantan dan 323 ekor betina dengan ukuran panjang total berkisar antara 46-117 mm (jantan), 61-126 mm (betina) dan bobot tubuh ikan berkisar antara 0,57-9,49 g (jantan), 2,36-16,72 g (betina).

Ukuran ikan C. cynoglossus betina pertama kali matang gonad pada panjang total $105,5 \mathrm{~mm}$ (Gambar 2). Ukuran ikan jantan pertama kali matang gonad tidak dapat diketahui karena tidak terdapat ikan yang matang gonad (TKG IV) di setiap bulan pengambilan contoh.

Tingkat kematangan gonad ikan betina ditemukan dalam berbagai tahap perkembangan gonad (TKG I-IV) terutama TKG IV yang ditemukan dari bulan Maret hingga Desember, sedangkan pada ikan jantan hanya ditemukan TKG I dan II (Gambar 3). Selama penelitian, baik pada ikan jantan maupun betina tidak ditemukan TKG V (ikan yang sudah memijah). Nilai indeks kematangan gonad ikan betina (TKG I-IV) berkisar antara 1,18-15,74 dan nilai tertinggi terdapat pada bulan Mei dan November, sedangkan pada ikan jantan (TKG I-II) berkisar antara 0,49-2,30 (Gambar 4).

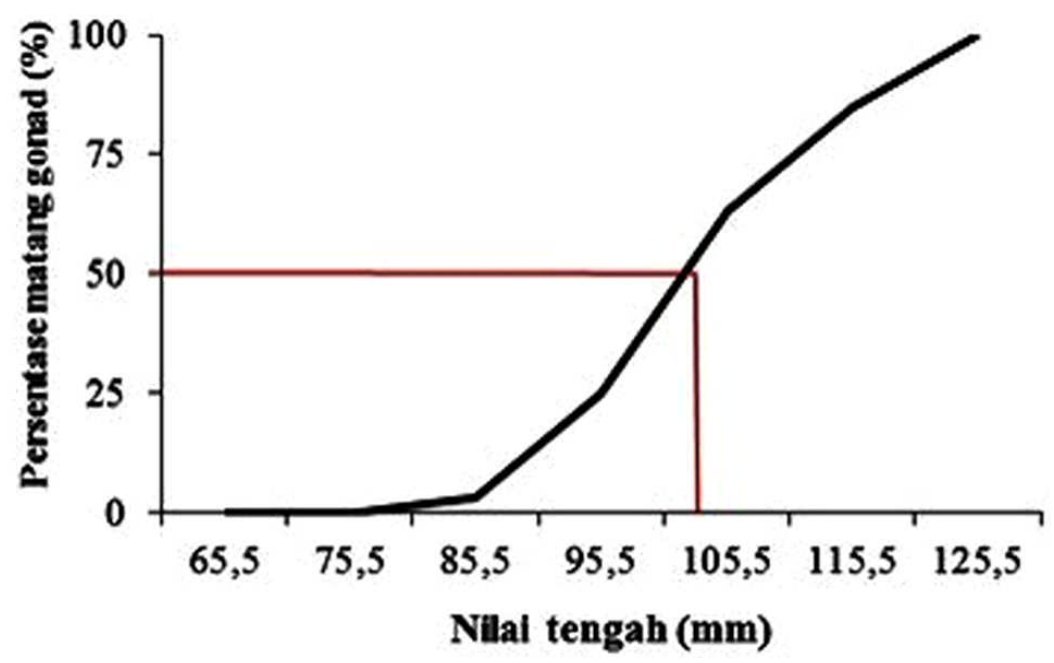

Gambar 2. Ukuran ikan C. cynoglossus betina pertama kali matang gonad (Lm50).

Figure 2. The length of tongue sole female at first sexual maturity (Lm50). 


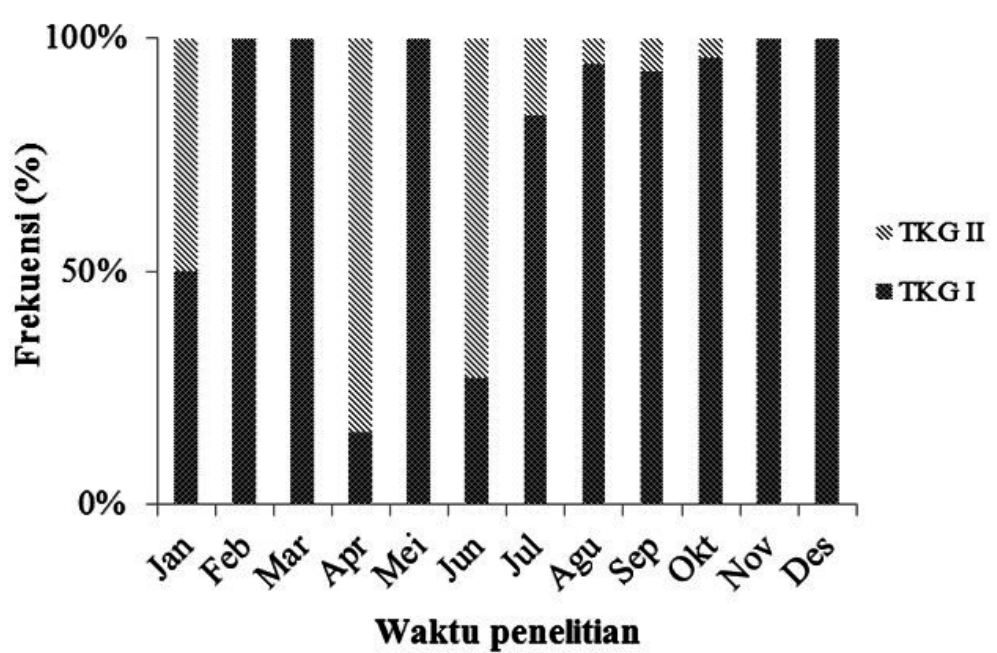

(a)

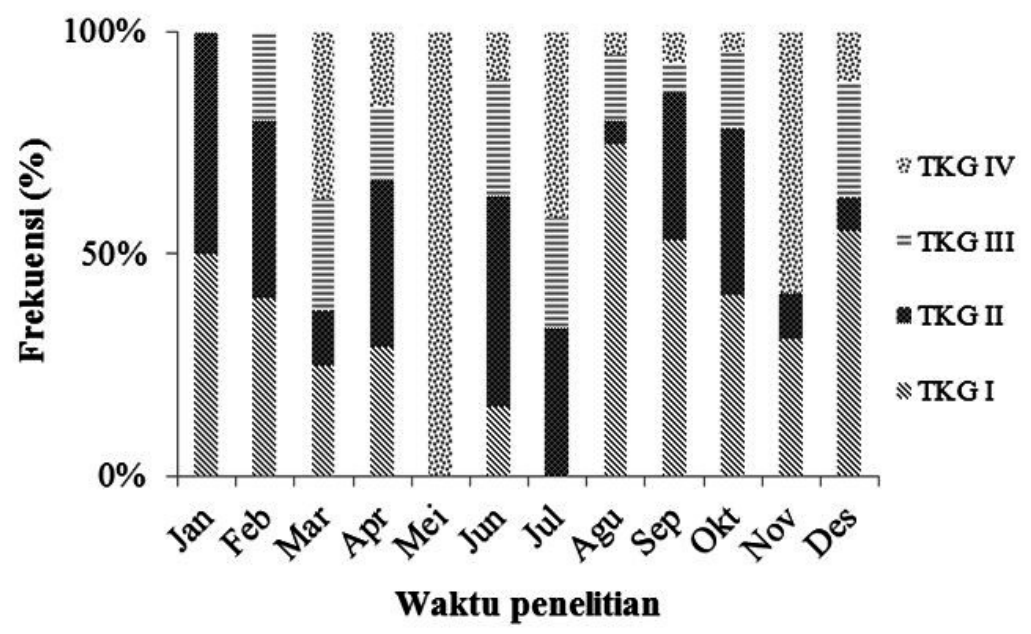

(b)

Gambar 3. Tingkat kematangan gonad ikan lidah jantan (a) dan betina (b). Figure 3. Gonad maturity stage of tongue sole (a) male and (b) female.

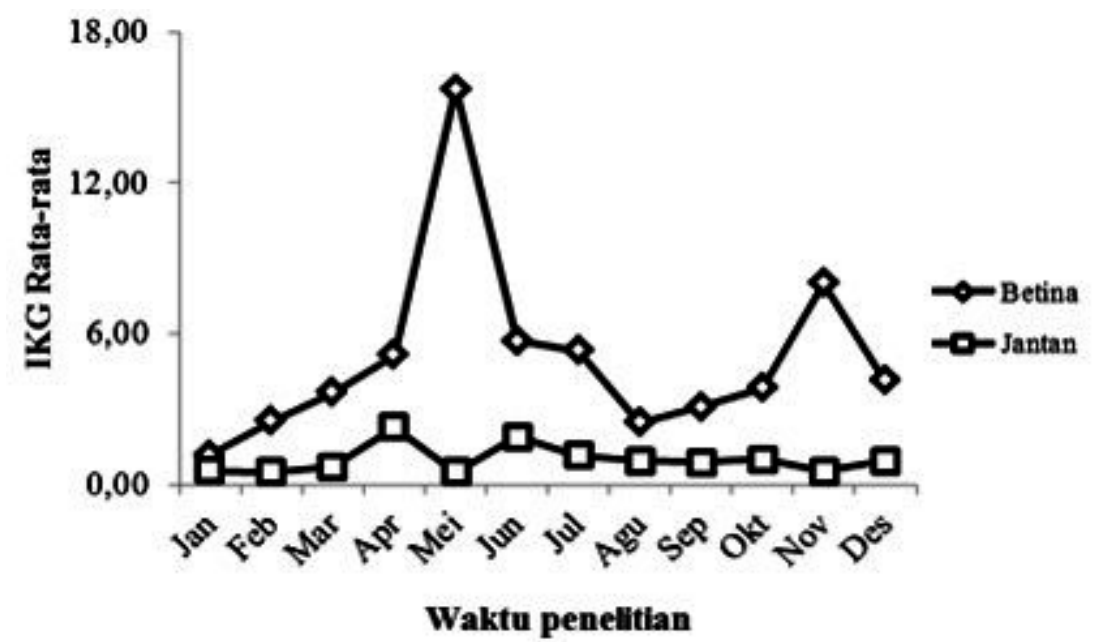

Gambar 4. Indeks kematangan gonad ikan lidah jantan dan betina.

Figure 4. Gonadosomatic index of male and female tongue sole. 
Fekunditas ikan lidah di Teluk Pabean berkisar antara 2.657-39.647 butir dengan kisaran panjang total ikan antara 96-125 mm. Fekunditas tertinggi ditemukan pada ikan yang panjang totalnya $125 \mathrm{~mm}$ (39.647 butir) dan yang terendah ditemukan pada ikan yang panjang totalnya $96 \mathrm{~mm}$ (2.657 butir). Hubungan antara fekunditas dengan panjang total ikan lidah dinyatakan oleh persamaan $\mathrm{F}=5 \times 10^{-6} \mathrm{~L}^{5,14}$ dan fekunditas dengan bobot tubuh ikan lidahF $=8,76 \mathrm{~W}^{3,02}$ (Gambar 5\&6).

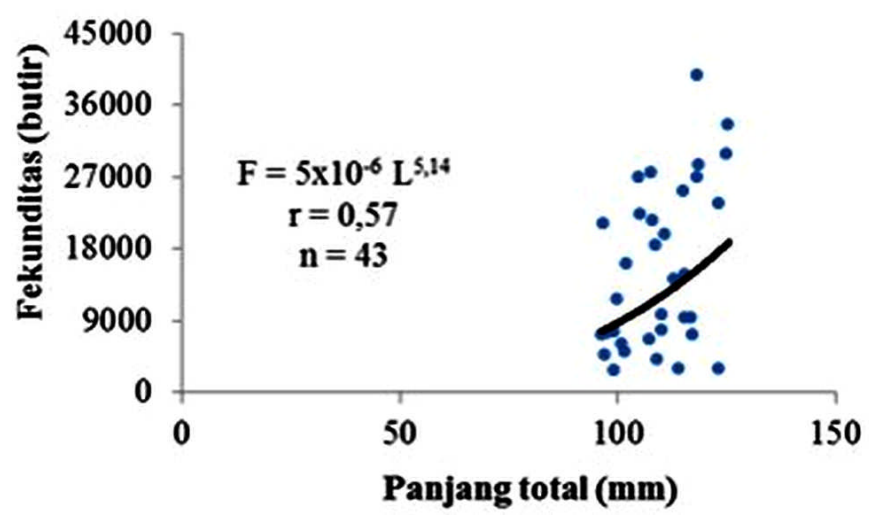

Gambar5. Hubungan fekunditas dengan panjang total ikan lidah.

Figure 5. Relationship of fecundity and total length of tongue sole.

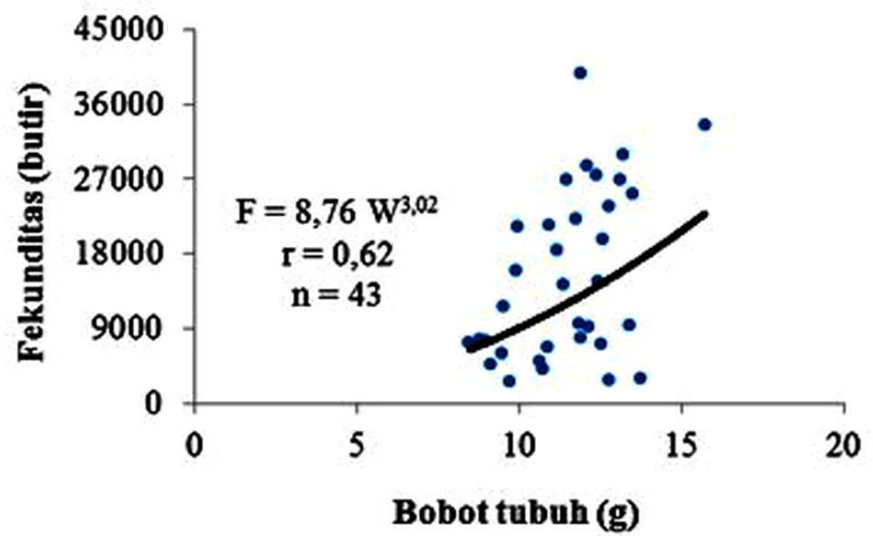

Gambar6. Hubungan fekunditas dengan bobot tubuh ikan lidah.

Figure 6. Relationship of fecundity individual weight of tongue sole.

Hasil pengukuran diameter telur ikan betina berkisar antara 0,23-0,76 mm. Berdasarkan Gambar 7, dapat diketahui bahwa pola penyebaran diameter telurnya membentuk dua modus. Modus pertama terdapat pada selang kelas antara
0,35-0,40 mm dan modus kedua pada selang kelas antara 0,59-0,64 mm. Ini menandakan bahwa ikan lidah di perairan Teluk Pabean termasuk pemijah bertahap (batch spawner).

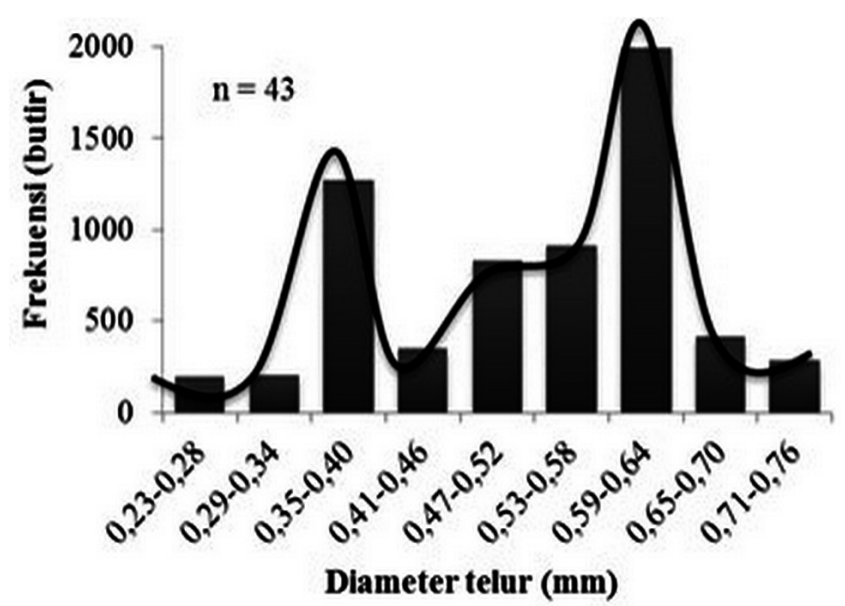

Gambar 7. Sebaran diameter telur ikan lidah.

Figure 7. Distribution of egg diameters of tongue sole. 


\section{Bahasan}

Panjang total ikan lidah di Teluk Pabean berkisar antara 46-126 mm. Menurut Carpenter \& Niem (2001) ikan yang tertangkap umumnya berkisar antara $100-150 \mathrm{~mm}$, panjang total maksimun mencapai $200 \mathrm{~mm}$. Di Pantai Mayangan untuk jenis C. bilineatus Zahid \& Simanjuntak (2009) menemukan panjang totalnya berkisar 80-369 mm. Untuk jenis C. lingua di Ujung Pangkah Sulistiono et al. (2009) memperoleh panjang total ikan berkisar $65-325 \mathrm{~mm}$.

Ukuran pertama matang gonad ikan betina lidah diduga pada panjang total $105,5 \mathrm{~mm}$. Sulistiono et al. (2009) memperoleh di Ujung Pangkah, ukuran pertama matang gonad C. lingua betina pada kisaran panjang total 94-122 $\mathrm{mm}$. Ukuran ketika mencapai matang gonad setiap spesies ikan berbeda, bahkan pada spesies yang sama namun habitatnya berbeda juga dapat ditemukan ukuran yang berbeda. Perbedaan ukuran ini disebabkan oleh kondisi ekologis pada setiap perairan yang memengaruhi kondisi biologis ikan, kualitas perairan, sifat genetik, dan besarnya tingkat penangkapan (Rahardjo \& Simanjuntak, 2007).

Berlangsungnya musim pemijahan ikan ditandai oleh adanya ikan yang bergonad matang; sedangkan tempat berlangsungnya pemijahan di suatu perairan ditentukan dengan ditemukannya ikan jantan dan ikan betina yang matang secara bersama-sama. Kepastian tempat pemijahan ditentukan oleh adanya pralarva di tempat tersebut (Rahardjo et al. 2011). Ditemukannya ikan lidah betina yang matang gonad pada bulan Maret hingga Desember, mengindikasikan bahwa musim pemijahan ikan ini berlangsung pada bulan-bulan tersebut. Bila dikaitkan dengan besaran IKG (Gambar 4), maka puncak pemijahan terjadi pada bulan Mei. Namun penelitian ini tidak menemukan ikan jantan yang matang gonad (TKG IV). Diperkirakan bahwa pada ikan ini terjadi pemisahan seksual (sex segregation), di mana ikan jantan dan betina terpisah secara spasial (Wearmouth \& Sims 2008). Menurut informasi, ikan C. cynoglossus jantan ada di perairan laut yang dalam. Hal ini diperkuat oleh Gerritsen et al. (2010) yang menyatakan bahwa ikan-ikan kelompok famili Cynoglossidae pada ukuran kecil ditemukan secara bersama. Setelah tumbuh dewasa, ikan jantannya berenang ke arah perairan yg lebih dalam dan ikan betinanya ke arah perairan yang dangkal untuk dapat tumbuh dan berkembang lebih cepat. Seitz et al. (2005), Ramos et al. (2010), dan Gibson et al. (2015) juga menambahkan bahwa sebagian besar ikan flatfish dari famili Cynoglossidae melakukan pemijahan di perairan laut yang dalam. Dari uraian ini dapat dikatakan bahwa ikan C. cynoglossus jantan dan betina akan bersama-sama melakukan pemijahan (mating) di perairan di luar Teluk Pabean pada perairan yang lebih dalam. Untuk memastikan tempat persis diperlukan satu penelitian lanjutan terkait dengan persebaran larva ikan di luar Teluk Pabean.

Di Pantai Mayangan untuk jenis ikan C. bilineatus betina musim pemijahan berlangsung dari bulan Juni hingga November (Zahid \& Simanjuntak 2009). Sulistiono et al. (2009) juga menambahkan bahwa musim pemijahan ikan $C$. lingua betina di Ujung Pangkah berlangsung dari bulan Agustus hingga Januari. Perbedaan musim pemijahan ini disebabkan oleh spesies ikan dan letak geografis.

Ikan C. Cynoglossus betina yang matang gonad (TKG IV) menyebar di perairan dangkal (teluk) untuk mencari makanan. Makanan tersebut berupa udang dan ikan-ikan kecil (Sihombing, 2016). Makanan ini dibutuhkan untuk mencukupi embrio dalam proses pembentukan gonad.

Fekunditas ikan C. cynoglossus di perairan Teluk Pabean berkisar 2.657-39.647 butir. Di Ujung Pangkah fekunditas $C$. lingua berkisar 360-35.926 butir (Sulistiono et al., 2009), sedang di Pantai Mayangan fekunditas $C$. bilineatus berkisar antara 2.323-225.557 butir (Zahid \& Simanjuntak, 2009). Variasi nilai fekunditas pada ikan dapat disebabkan oleh adanya ikan yang baru pertama kali memijah dan sudah pernah memijah serta adanya variasi ukuran ikan tersebut. Ikan yang sudah beberapa kali memijah memiliki nilai fekunditas lebih tinggi dibandingkan dengan ikan yang baru pertama kali memijah. Nikolsky (1963) menyatakan bahwa nilai fekunditas dipengaruhi oleh kondisi lingkungan dan predator. Ikan yang hidup pada perairan yang kurang subur memiliki produksi telur yang rendah, sedangkan ikan yang hidup dengan kondisi predator dalam jumlah banyak memiliki fekunditas yang besar. Perbedaan nilai fekunditas juga dapat diduga karena dipengaruhi oleh faktor umur dan spesies.

Fekunditas ikan lidah tidak memiliki hubungan yang signifikan dengan panjang total ikan dan bobot tubuh ikan karena rendahnya nilai korelasi pada Gambar $5 \& 6$. Rendahnya korelasi ini diduga karena ikan memiliki ukuran panjang yang hampir sama bahkan sebagian besar memiliki ukuran yang sama dengan fekunditas yang bervariasi. Menurut Effendie (2002), variasi jumlah telur ikan disebabkan oleh adanya variasi kelompok ukuran ikan. Berbeda halnya dengan ikan C. bilineatus dan ikan sebelah famili Cynoglossidae lainnya bahwa fekunditas memiliki hubungan yang signifikan antara panjang total dan bobot tubuh ikan (Rijnsdorp \& Witthames, 2005; Zahid \& Simanjuntak, 2009).

Pola sebaran diameter telur ikan lidah membentuk dua modus, itu artinya bahwa ikan lidah termasuk pemijah bertahap. Hal yang sama juga ditemukan pada ikan $C$. bilineatus di perairan Pantai Mayangan (Zahid \& Simanjuntak, 2009) dan ikan C. lingua di Ujung Pangkah (Sulistiono et al., 2009). 


\section{KESIMPULAN}

Hasil penelitian menunjukkan panjang total ikan lidah jenis $C$. cynoglossus berkisar antara 46-126 mm dengan bobot tubuh antara 0,57-16,72 g; ikan jantan relatif lebih kecil. Ikan lidah termasuk kelompok pemijah bertahap dengan musim pemijahan berlangsung dari bulan Maret hingga Desember dan puncak pemijahan pada bulan Mei. Dugaan ikan lidah betina pertama matang gonad pada panjang total ikan 105,5 mm dengan jumlah telur berkisar antara 2.657-39.647 butir. Perlu dilakukan penelitian lanjutan berupa inventarisasi larva dan yuwana di bagian luar dan dalam Teluk Pabean untuk memastikan tempat pemijahan ikan ini dan pertumbuhan ikan pada stadia perkembangan awal (early development stage).

\section{PERSANTUNAN}

Ucapan terima kasih penulis sampaikan kepada mitra bebestari yang telah menelaah dan memberikan masukan berharga.

\section{DAFTAR PUSTAKA}

Bal, D. V. \& Rao, K. V. (1984). Marine fisheries of India (p. 472). Tata McGraw-Hill Publishing Company Limited, New Delhi.

Carpenter, K. E. \& Niem, V. H. (eds.). (2001). FAO species identification guide for fishery purposes. The living marine resources of the Western Central Pacific. Volume 6 Bony fishes part 4 (Labridaeto Latimeriidae), estuarine crocodiles, sea turtles, sea snakes and marine mammals. (p. 3381-4218). Rome, FAO.

Damalas, D., Katsanevakis, S., Maravelias, C. D., \& Karageorgis, A. P. (2009). Habitat selection of flatfish in relation to spatial, temporal and environmental parameters in the Aegean sea. Proceedings 9th Symposium on Oceanography \& Fisheries 2009. 2, 777-782.

Effendie, M. I. (1979). Metode biologi perikanan. (p. 112). Yayasan Dewi Sri, Bogor.

Effendie, M. I. (2002). Biologi perikanan. (p. 163). Yayasan Pustaka Nusatama, Yogyakarta.

Gerritsen, H. D., McGrath, D., Lordan, C., \& Harlay, X. (2010). Differences in habitat selection of male and female megrim (Lepidorhombus whiffiagonis, Walbaum) to the west of Ireland. A result of differences in life-history strategies between the sexes?. Journal of Sea Research, 64(4), 487-493.
Gibson, R. N., Nash, R. D. M., Geffen, A. J., \& Van Der Veer, H. W. (2015). The behaviour of flatfishes. In Gibson, R. N. (ed.) Flatfishes: Biology and Exploitation (second edition). (p. 314-317). Blackwell Science Ltd: Blackwell Publishing Company, New York.

Jennings, S., \& Lock, J. M. (1996). Population and ecosystem effects of fishing. In: Polunin, N. V. C. \& Roberts, C. M. (ed.). Reef Fisheries. (p. 193-218). Chapman and Hall, London.

Jennings, S. \& Kaiser, M. (1998). The effects of fishing on marine ecosystems. Advances in Marine Biology, 34(34), 201-352.

Kramer, SH. (1991). The shallow-water flatfishes of San Diego Country. California Cooperative Oceanic Fisheries Investigations Reports, 32, 128-142.

Munroe, T.A. (2005) Distributions and biogeography, in Flatfishes: Biology and Exploitation, 1st edn (ed. R.N. Gibson), Blackwell Science, Ltd, Ames, IA, pp. 42-67.

Nelson, J. S. (2006). Fishes of the World. (p. 601). Fourth edition John Wiley \& Sons, Inc., Hoboken, New Jersey.

Nikolsky, G. V. (1963). The Ecology of Fishes. (p. 352). New York, Academic Press.

Pauly, D., Christensen, V., \& Walters, C. (2002). Ecopath, ecosim and ecospace as tools for evaluating ecosystem impacts of ûsheries. ICES Journal of Marine Science, 57(3), 697-706.

Rahardjo, M. F. (1987). Ecobiologie et dynamique des populations de poissons dans le Reservoir Bening, Java de l'Est, Indonesie. Thesis. Institut National Polytechnique de Toulouse.

Rahardjo, M. F., \& Simanjuntak, C. P. H. (2007). Aspek reproduksi ikan tetet Johnius belangerii Cuvier (Pisces: Sciaenidae) di Pantai Mayangan, Jawa Barat. Jurnal Perikanan, 9(2), 200-207.

Rahardjo MF, Sjafei DS, Affandi R, Sulistiono. (2011). Iktiology (p. 394). Bandung: Lubuk Agung.

Ramos, S., Pedro, R. E., \& Bordalo, A. A. (2010). Recruitment of flatfish species to an estuarine nursery habitat (Lima Estuary. NW Iberian Peninsula). Journal of Sea Research, 64(4), 473-486.

Rijnsdorp, A. D. \& Witthames, P. R. (2005). Ecology of reproduction. In Gibson, R. N. (ed.) Flatfishes: Biology and Exploitation. (p. 68-93). Blackwell Science Ltd: Blackwell Publishing Company, New York 
Seitz, A. C., Norcross, B. L.,Wilson, D., \& Nielsen, J. L. (2005). Identifying spawning behavior in Pacific halibut, Hippoglossus stenolepis, using electronic tags. Environmental Biology of Fishes. 73(4), 445-451.

Shabana, N. M. A., El Rahman, S. H. A., Al Absawy, M. A., \& Assem, S. S. (2012). Reproductive biology of Argyrosomus regius (Asso, 1801) inhabiting the southeastern Mediterranean Sea, Egypt. Egyptian Journal of Aquatic Research. 38(2), 147-156.

Sihombing, D. P. (2016). Makanan ikan lidah Cynoglossus cynoglossus Hamilton 1822 (Pisces: Cynoglossidae) di Teluk Pabean, Jawa Barat. Prosiding Seminar Nasional Ikan ke-9. (p. 8, 1-11). Jakarta, Indonesia: Sekolah Tinggi Perikanan, Jakarta.
Sulistiono, Soenanthi, K. D., \& Ernawati, Y. (2009). Aspek reproduksi ikan lidah Cynoglossus Lingua (Hamilton Buchanan 1822) di Ujung Pangkah, Jawa Timur. Jurnal Iktiologi Indonesia. 9(2), 175-185.

Wearmouth V.J. \& Sims D.W. 2008. Sexual segregation in marine fish, reptiles, birds and mammals, In: David W Sims: Advance in Marine Biology 54. Academic Press, London. pp. 107- 170.

Zahid, A., \& Simanjuntak, C. P. H. (2009). Biologi reproduksi dan faktor kondisi ikan ilat-ilat, Cynoglossus Bilineatus Lac. 1802 (Pisces: Cynoglossidae) di Pantai Mayangan, Jawa Barat. Jurnal Iktiologi Indonesia. 9(1), 85-95. 
Gustiarisanie, A., et al/BAWAL. 9 (2) Agustus 2017: 103-112

Lampiran 1. Ikan lidah jenis Cynoglossus cynoglossus (Sumber: Dokumentasi Pribadi)

Appendix 1. Species Cynoglossus cynoglossus (Source: Personal Documentation)

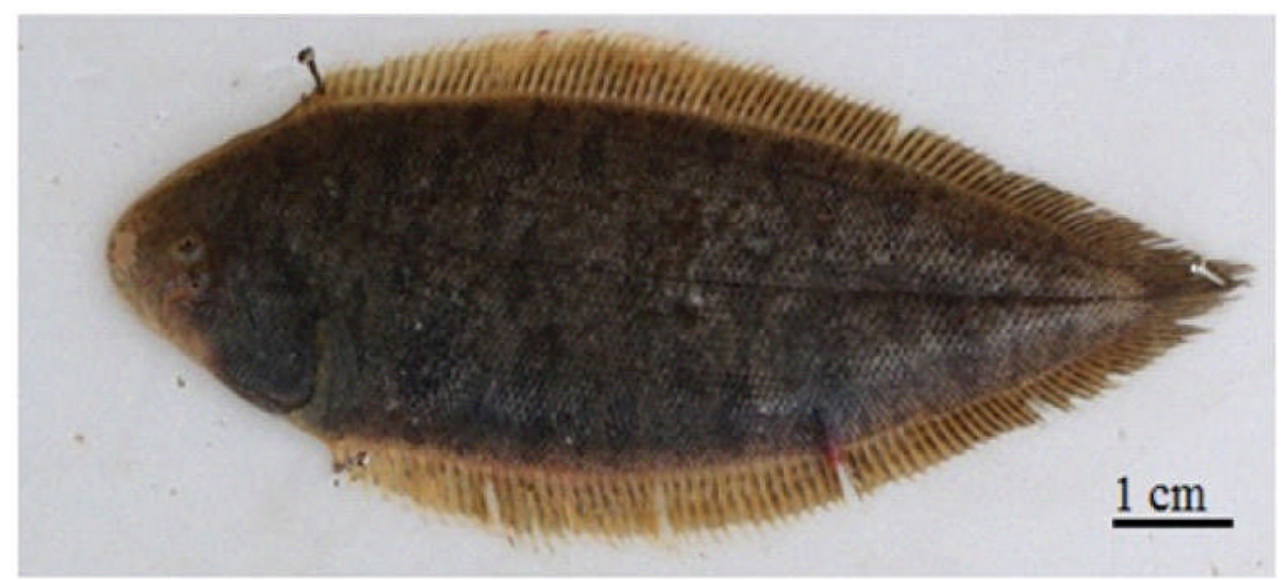

Lampiran 2. Tingkat Kematangan Gonad Ikan lidah di Teluk Pabean

Appendix 2. $\quad$ Gonad maturity stage of tongue sole in Pabean Bay

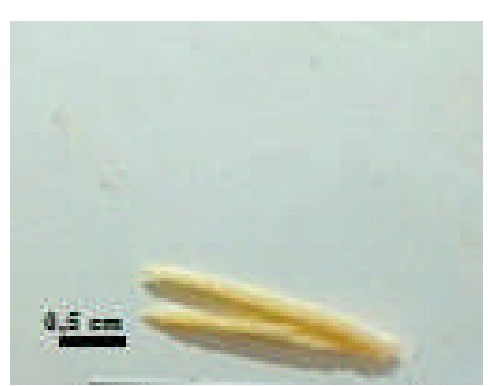

TKG I

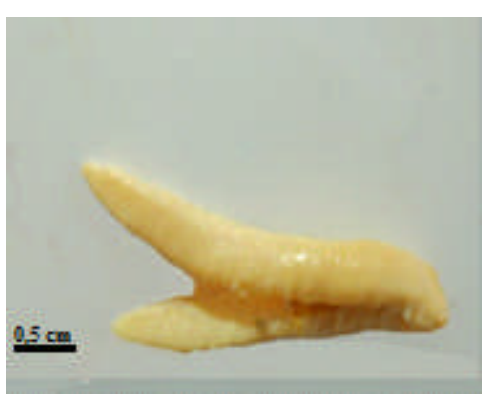

TKG III

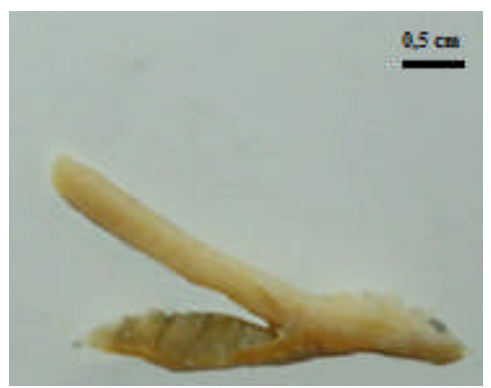

TKG II

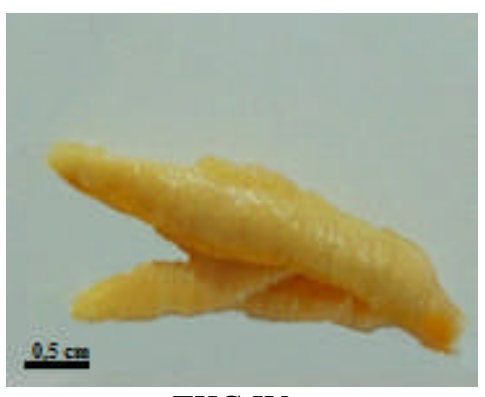

TKG IV

Lampiran 3. Tingkat kematangan gonad ikan C. cynoglossus jantan

Appendix 3. Gonad maturity stage of male tongue sole

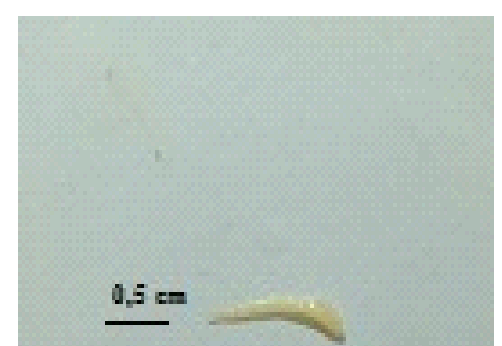

TKG I

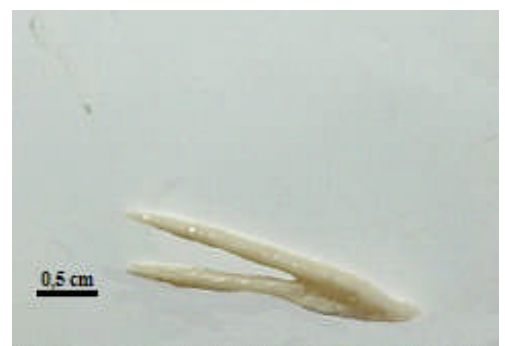

TKG II 